\title{
Islamic Modernists and Discourse on Reason as a Reconciliatory Argument between Islam and the Western Enlightenment
}

\author{
ASMAHAN SALLAH ${ }^{1}$
}

\begin{abstract}
This article examines the debates on the relationship between Islam and reason during the nineteenth century and early twentieth century. It argues that these debates were transnational but were largely influenced by similar debates in the Western tradition. It also affirms that modernists used discourse on reason to reconcile Islam with Western Enlightenment. The article illustrates the various mechanisms which Islamic modernists implemented to facilitate such reconciliation. These mechanisms include rationalization of miracles, contesting the concept of prophethood, and rejecting the scholarship of Islamic jurisprudence and theology. Based on writings by several Islamic modernists, such as their biographies of Prophet Muhammad, Quran commentaries, and magazine articles in different Islamic countries, I ascribe these mechanisms to a gap between logic and experimental thought, a gap which seeped into the mind of Islamic modernists under the influence of Western contemporary thinkers. While this discourse claims compatibility between Islam and Western Enlightenment, it also resists the binary of the sacred and the secular, a major legacy of the Western Enlightenment.
\end{abstract}

Keywords: Enlightenment, modernist Muslims, reason, secularism

In an elegiac poem that mourns Muhammad Abduh, Hafiz Ibrahim (an Egyptian renowned poet 1872- 1932) (1978) describes the Islamic reformer's contributions to challenging the Orientalist views of Islam, writing:

Religion, reason, and argumentation, you reconciled, And from these three directions, light you withdrew. Against Hanoto and Renan, you stood self-composed, And Behind you, the angels' spirit of wisdom blew.

In these four lines, refers to Abduh's attempt of reconciliation between religion and reason as light coming out of three different entities, implying that this reconciliation is a worthy intellectual endeavor that leads to enlightenment. The fact that the attempts of such reconciliation became a subject of cultural commentary in a poem by the famous 'poet of the Nile' indicates the significance given to this intellectual project in the public sphere. Moreover, the symbolism of light recalls to one's mind the cultural and global context of these debates which were building on the ideas of Western Enlightenment. This essay examines these discussions on reason and religion which took place during the Arab renaissance extending roughly between 1850 and 1950, a period which also witnessed the beginning of what came to be known as Islamic Reformation. My focus in examining these debates is on how the different parties involved in it viewed the relationship between reason and Islam particularly in the

\footnotetext{
1 Asmahan Sallah, Ph.D., Assistant Professor, Dept. of Languages \& Literatures, College of Letters \& Sciences, University of Wisconsin-Whitewater, WHITEWATER, WI 53190-1790, United States, email: sallaha@uww.edu.
} 
course of investigating the compatibility between secularism and Muslim societies at the turn of the twentieth century. The discussions, exchange of views, and the debates were available through magazines, books, and other media venues. Mustafa Sabri Efendi, the last Sheikh AlIslam of the Ottoman Empire, recorded some of these exchanges among Egyptian thinkers in his four volume book. Perhaps Sheikh Sabri Efendi (1981) was the first author to offer an overview of these discussions in his attempt to provide a response to Islamic modernists. My article expands on Sabri's observations to argue that Islamic modernists used discourse on reason to reconcile Islam with the Western Enlightenment. In addition to expanding on Sabri's observations, I show how the rationalization pattern adopted by Islamic modernists in Egypt was twofold, transnational and transcultural. It was transnational because Islamic modernists in Africa, represented by Egyptian modernists, and in Asia, represented by Indian Islamic modernists, articulated the same pattern of rationalization. The rationalization pattern was also transcultural because it reflected the influence of the discussions that took place over the role of reason in the Christian-Western tradition. Not only were Islamic modernists influenced by the Enlightenment paradigm, but also their own debates reflected previous discussions within the Western history between the Church leaders and the Enlightenment thinkers. I will show the various mechanisms through which Islamic modernists tried to rationalize Islamic beliefs inspired by Western Enlightenment. These mechanisms include interpretation and rationalization of miracles, foregrounding the abstract aspects of Muhammad's prophethood, such as the social upheaval that it caused, differentiating between Aristotelian logic and empirical proof, and finally rejecting Islamic jurisprudence and theology scholarship as a product of logic that lacks the certainty of experimental knowledge.

In her book on the reformist tradition within Islam, Samira Haj (2009: 190) discusses the 'invalid oppositional construction between the sacred as nonrational and the secular as rational and the assumption thereof that Islamic discourses are inherently nonrational'. She refers to the fabrication of this binary construct when she mentions that 'Muslims' disinclination toward rationality is claimed to have originated in early Islam . . . and is specifically traced back to the conflict between religion (Muslim theologians and jurists) and reason (rationalists and philosophers), which resulted in the defeat of rationalism and the in the triumph of traditionalism'. While Haj argues convincingly that this conflict is only a flawed construction 'imposed by earlier scholars', al-Ansari's (1996) reading of the conflict between reason and religion in the minds of Islamic reformists fails to see the nuances within the Islamic discourse. Al-Ansari argues that Islamic reformists' insistence on reconciling reason and religion is one of the factors that led to the failure of their efforts geared towards reconciling European modernity with Islamic societies. Drawing on Ibrahim al-Labban's Al-falsafah wa almujtama al-Islami (Philosophy and Muslim society), he ascribes this failure to the Islamic modernists' lack of understanding that reason in Western civilization had already developed into forms different from those Platonic or Aristotelian. Against Al-Ansari, I want to show that Islamic reformists did in fact move away from metaphysical reason through their celebration of empiricism as a criterion for the certainty of knowledge, rather than Aristotelian logic.

In the Western Enlightenment studies cannon, researchers agree that the paradigm of Enlightenment includes among other ideas the modern emphasis on rationality, empiricism, and science. The Enlightenment thinkers 'stressed the primacy of rationality as a way of organizing knowledge tempered by experience and experiment. In this, they took over the rationalist concept of reason as the process of rational thought, based upon clear, innate ideas independent of experience' (Hamilton 1996). Rationality that relies on such a paradigm was understood in terms of empiricism, 'the idea that all thought and knowledge about the natural and social world is based on empirical facts, things that all human beings can apprehend through their sense organs'. In such a paradigm, 'scientific knowledge based on the experimental method as developed during the scientific revolution of the $17^{\text {th }}$ century was the key to expanding all human knowledge' (Hamilton 1996). In other words, at least in one of its interpretations, the 
European Enlightenment may have restricted the meaning of reason to its facilitation of experimentalism and the progress of scientific knowledge. Within this pattern of knowledge structure, modernization brought along with it the exclusion of religion from the realm of state. Religion is allied with irrationality, while the state has to be founded on clear rational and experimental principles about the world and organizing it. The need to negotiate their position between reason, state, and religion is the challenge that faced Arab and Muslim thinkers at the turn of the twentieth century as a result of their contact with Western modernity.

\section{Secularism in Language and Muslim Societies: Outlining the Debate}

The association between secularization - understood as the separation between religion and sate - and science was so strong that it affected the translation of the word 'secularism' in Arabic. Secularism was translated into Arabic as either 'ilmaniyah or 'almaniyah, where 'ilmaniyah is morphologically associated with 'ilm meaning science, while 'almaniyah is associated with that which is worldly and mundane. The latter form of translation bears with it semantic kinship to the 'secular'. Both forms, however, are originally derived from the threeconsonant root verb 'ilm ( 1 ), having to do with 'knowledge'; accordingly, both forms of the translation in Arabic are morphologically bound to epistemology or ways of knowledge. The translation of 'secularism' as such, then, does not reflect a necessary opposition between the sacred and the secular. Because of this morpho-semantic characteristic of the word, secularism in the Arab world not only came to 'describe a process aimed at the marginalization of Islam, or its exclusion from the process of restructuring society during both the colonial and postindependence periods' (Tamimi 2000), but it more importantly implied 'commitment to science' in social and political practices. For many Islamic modernists during that period, this commitment to science needed not to contradict religion; hence, it was possible for modernization to be effected in Islamic societies while engaging Islam in the process of governance. The interlocutors in the debates over reason, religion, and secularism were the Islamic modernists such as al-Afghani and Abduh and their students; intellectual secularists, both Christian and Muslim; and classically trained scholars of religion or conservatives. Farah Antun's discussion with Muhammad Abduh provides a good context for the debate in its entirety and sheds a light on the nuances of the discourse amongst Islamic modernists themselves.

Farah Antun (1874-1922), a Christian secularist and mostly celebrated as the prominent figure in the history of Arab secularism, records his debate with Sh. Muhammad Abduh (18491905) in his Ibn Rushd wa Falsafatuh (Averroes and His Philosophy). In his vision of a civil society in the Arab world that emulates the European model, Antun (1988: 41,210) dedicates his book to the 'rationalist Easterners in Islam and Christianity and others who are aware of the harm that ensues from mixing the mundane world with religion in this age', and demands that their religions be put aside in a holy place, 'so that they can achieve a real unity amongst themselves and be able of catching up with the current of new civility'. The real unity amongst followers of different religions, can for Antun, be achieved only through a commitment to reason and rationality which have no relation to any religion whatsoever, so they can be a good site for people from different religious backgrounds to come together in their effort to restructure their society.

Antun (1988) expresses his opinion of the necessity of a strict separation between religion and reason through a spatial metaphor. Religion resides in the heart, while reason and science reside in the mind. The subtext of Antun's spatial distinction between reason and religion betrays his belief in the principle of the separation between religion and the state through the separation between reason and religion. He uses the words science and reason interchangeably, only restricting his discussion to reason when he quotes or discusses Ibn Rushd's statements on the relationship between reason and religion from a philosophical 
perspective. Science, Antun (1988: 210) concludes, should belong to the sphere of reason because the bases of science are grounded in seeing, in experimenting, and in testing. Religion, however, should be put in the sphere of heart because the bases of religion are grounded in belief in whatever is cited in books without looking into their origins'. Unlike Islamic modernists, Antun (1988: 290-91) in this quote considers that contents of the sacred books of religion, in addition to other components of religion, are out of the scope of scientific investigation. For Antun, all basics of religion, including the Abrahamic religions, cannot be tested for their truth. Religion, as he defines it, is the belief in an invisible creator and an invisible afterlife, revelation, prophecy, judgment day, reward, and punishment, all of which are not tangible entities and have no evidence to their existence except for what is stated in holy books. Those who seek a rational understanding of these matters in order to claim that their religion is rational will necessarily end up eliminating their beliefs in those matters. 'That is why', he says: "we divided the human being in volume nine of Al-Jami 'a (-the magazine of which he was chief editor and on whose pages the debate with Muhammad Abduh took place) into a mind and a heart".

Antun (1988: 211), then, restricts the meaning of rational understanding to whatever can be understood through senses. He sees that inclusion of religion within the realm of scientific investigation is a vain attempt, saying that if 'religion attempts to pressurize reason, reason will scream back at it, saying leave me alone. I do not believe in anything and would not take it into my account unless I see it in my bare eyes and test it with Bacon'. Also, unlike early Islamic modernists, Antun (1988: 236) thinks that this strict isolation of reason and religion is universal and should be applied to all religions:

The real enemy of Islam, Christianity, Judaism, Buddhism, Confucianism, and paganism is not from within, but an outside enemy, an enemy which the new civilization has presented ... This enemy ... is the 'materialist principles' grounded in research that is driven by reason alone .... Accordingly, the followers of Islam and Christianity should not be tempted to discuss their tenets, thereby giving that enemy a weapon with which to fight them. The reasonable followers of both religions know that if reason destroyed Christianity, it would also destroy Islam.

Because all religions are in a battle with reason, Antun (1988: 206) is quick to alert the reader in the introduction that any 'phenomenon that reason and scientific evidence do not explain should be interpreted', implying that religious phenomena could be explained by resorting to interpretation, so they could be accepted as metaphoric or symbolic not literal. Antun's approach to the relationship between reason and religion is fundamental to any conceptualization of his contemporary Islamic modernists' views of the compatibility between Islamic societies and the Western Enlightenment. Antun called for a complete separation between religion and the state; as a response, many Islamic modernists insisted that this separation is not necessary and suggested many formulas for religious reform to support their arguments and reformation projects. Although these responses are varied and can be inconsistent even in one thinker's writings, their trajectory is a function of the changing definitions of reason that Islamic modernists adopted in their works. Because Islamic modernists were exposed to Western thought especially through their study travels to Europe (see also Anouar Louca, Voyageurs et Ecrivian Egyptiens en France au 19 Siecle. Paris: Didier, 1970) many of the arguments they raised had counterparts in the Western Enlightenment. Thus, a debate that once took place amongst European Enlightenment thinkers and their interlocutors, mostly Christian theologians, repeated itself amongst the pioneers of Islamic modernism who displayed different degrees of commitment to traditional Islam. 


\section{Debates on the Role of Reason in the Western Tradition}

In fact, the controversy over the role of reason within the Christian-Western tradition also featured the definition of reason as a turning point for negotiating the duality between faith and reason. The discussion surrounding this emergent duality was multilayered. It concerned basic tenets of faith, miracles, revelation, and the scripture itself, topics which will also appear in the controversies among Muslim modernists, centuries later. It was John Locke (1990) who first maintained in his An Essay concerning human understanding that faith and reason relate to separate realms of knowledge, saying that 'setting down strict boundaries between faith and reason' should be 'the first point established in all questions where faith has anything to do'. Locke defined reason as 'the discovery of the certainty of probability of such propositions or truths which the mind arrives at by deduction made from such ideas, which it has got by the use of its natural faculties; viz. by sensation or reflection', while faith 'is the assent to any proposition, not thus made out by the deductions of reason, but upon the credit of the proposer, as coming from God, in some of communication. This way of discovering truths to men, we call revelation'. Because Locke assigned separate realms of knowledge to faith and reason, he 'nowhere stated precisely how reason could judge something to be divine, nor did he offer a systematic case for the probability that the Christian Scriptures were a divine revelation'. Likewise on the topic of miracles, Locke 'asserted the necessity of reason's judging what is and what is not a miracle', but in assessing reason's ability to make such judgments, 'he concluded his remarks by affirming that in regard to the Bible "The miracles were to be judged by the doctrine and not the Doctrine by the miracles', (Locke \& Higgins-Biddle 1991: cxi), possibly implying that miracles should be accepted as long as they confirmed doctrines that do not contradict reason. Higgins-Biddle notes rightly that accusing Locke of 'failing to provide rational grounds for the truth of doctrines, for revelatory character of Scripture, and for miracles is not accurate because it does not take into account Lock's defining of reason's judgment in these matters to be that of determining probability, not demonstrating certainty .

One year after Lock's The Reasonableness of Christianity, Irish John Toland (1670-1772) published his Christianity not Mysterious in which he defined reason as 'that faculty of the Soul which discovers the Certainty of anything dubious or obscure, by comparing it with something evidently known' (Breuninger 2009). Although he followed Locke in maintaining that 'reason alone could and must determine whether something was a divine revelation' (Locke \& HigginsBiddle 1991), he asserted a relationship between reason and the content of revelation that was different from Locke's views. Toland 'refused to accept anything that could not be confirmed by one's 'natural,' 'common notions,' or 'clear Perceptions. Toland support of reason as a method to understand God', was criticized by religious public figures. When Synge Edward (1659-1741), Archbishop of Tuam, critiqued Toland's position, he did so through a careful redefinition of reason in his Gentleman's Religion (published in 1698). In divergence from both Locke and Toland, Synge surmised, for example, that revelation, 'or the Testimony of another' is not only $a$ means of Information, but also a motive of Perswasion'. This means that as long as revelation works its way to the hearts and minds of people by motivating them to do good deeds, it should not be investigated on the level of its dissonance with reason. Giving priority to the function of revelation rather than its epistemic validity, Synge 'dismissed Toland's contention that human understanding of the divine was not in accordance with reason' and maintained that some truths could be above reason Breuninger (2009). In fact, both Toland and Locke were accused of deism because of their theses regarding the separation between religion and reason, an accusation that will also implicate some of the Islamic modernists because of their attempt to subject religious beliefs to the judgment of reason. 


\section{The Views of Islamic Modernists in Egypt}

Muhammad Abduh, who was a leading religious figure, interpreter of Islamic law in Egypt, and a pioneer of religious reformation rejected Antun's strict separation between reason and religion; however, he made use of the 'interpretation' argument to suggest a conciliatory articulation of the relationship between reason and religion. If Antun's conviction of the separation between reason and religion is another facet of his belief in the necessity of the separation between religion and the state, Abduh attempted to disprove both as cause and effect arguments. To argue against the rift between religion and reason, Abduh relied on Ibn Rushd also, reconstructing him as a metaphysical philosopher who believed that reason and religion can be reconciled. For the separation between religion and the state, he challenged Antun with lengthened discussions over the following questions: can the king who rules a nation rid himself of his own beliefs? How can any ruler achieve a separation between the bodies and souls of the ruled? In addition, he refused to believe that toleration, as Antun thought, can only be achieved if the separation between religion and the state can be maintained. Abduh claimed that even the 'Give what is Cesar's to Cesar and what is God's to God' principle does not have to be explained against the backdrop of secularity (quoted in Antun 1988). Interestingly, however, Abduh carried out a process of reconciliation between reason and religion-and later between Islam and the Western Enlightenment, that Antun recommended, namely through interpretation of some religious elements and concepts, such as miracles and prophethood.

Like mainstream thinkers of Islam, Abduh (2004) in principle believes that miracles are not impossible to take place; thus, they do not impose a challenge for reason in the minds of those who believe in God. In his Risalat al-Tawhid, (-hereafter documented as The Theology of Unity, the title of the translation which I am using) he states: "[o]ur claim is that He who shaped the law is He who gave the creatures being. It is by no means impossible for Him to lay down special laws for what contravenes normal processes" (p. 79). This opinion, however, does not stay consistent throughout his other writings and his career for various reasons; one of them may be his rather ambiguous attitude towards the relationship between revelation and reason. Roxanne Euben (1999: 111-112) assesses Abduh's attitude through citing other scholars' opinions of his writings and through her own reading of The Theology of Unity. After citing other scholars' opinions who either doubted Abduh's mental agility to carry out such philosophical endeavor or thought that he was avoiding elaboration on such issues as the relationship between reason and revelation to 'avoid conclusions that would divide rather than unite Muslims', Euben agrees with Sharabi that Abduh's 'own writing makes it difficult to avoid the conclusion that the purported unity of reason and revealed truth has developed into a subordination of reason to the affirmation of fairly orthodox articles of faith'. However, she concludes her discussion by stating that 'Abduh's tenuous balance between reason and revelation is inadvertently tipped in favor of reason. By encouraging rational reinterpretation of revealed law when necessary, Abduh unintentionally grants reason an extraordinarily wide scope. I want to qualify Euben's reading of Abduh's attitude towards reason in two points through looking at other writings by Abduh in addition to his The Theology of Unity and then integrate that qualification in my argument. First, Abduh is inconsistent regarding his attitude towards reason. To express this inconsistency by saying that he 'unintentionally' tips reason over revelation does not change the fact that he, in a contradictory fashion, accepts the possibility of revelation only to suspect its credibility. Second, Euben (1999: 108) writes that reason means for Abduh 'the exercise of critical judgment on the basis of logical and empirical proof'; I see that Abduh's inconsistency can be explained by considering the gap between logical and empirical proof which came to exist in the mind of Islamic modernists after their contact with the knowledge paradigm of the Enlightenment. Abduh shares with Islamic Modernists, if has not initiated, the bias towards empirical proof against logical proof, most probably because of his being under the influence of modern European scientific thought. 
In The Theology of Unity, Abduh presents many examples of the Qur'anic exhortation to exercise reason. He also illustrates how religious truths such as God's existence and prophethood can be established rationally. The influence of the modern concept of reason which relies on empirical evidence can be manifested in his recourse to interpretation in cases where revelation and empirical evidence seem to be in conflict. Abduh (2004: 107-8) states:

Having, however, once recognized the mission of a prophet, reason is obliged to acknowledge all that he brings, even though unable to attain the essential meaning within it or penetrate its full truth. Yet this obligation does not involve reason in accepting rational impossibilities such as two incompatibles or opposites together at the same time and point. For prophecies are immune from bringing such follies. But if there comes something which appears contradictory reason must believe that the apparent is not the intended reason. It is then free to seek the true sense by reference to the rest of the prophet's message in whom the ambiguity occurred, or to fall back upon God and His omniscience.

An example that illustrates the implications of Abduh's argument in the previous passage comes from his famous commentary on the Quran. In this commentary, Abduh denies the literal acceptance of the miracle that led to the defeat of Ethiopian army which headed towards Mecca with the intention of destroying the Ka'ba. The leader of the Ethiopian army thought that destroying the Ka'ba will put an end to Arabs monopoly of the economic yield of the pilgrimage season in the Arab peninsula and surrounding regions. According to the Quranic account, God sent birds that threw stones at the Ethiopian army. Under the harm caused by these stone missiles, the Ethiopian army withdrew its forces. Standard and classical commentaries on Al-Feel Chapter (The Elephant Chapter) accept the Quranic verses as a manifestation of the miraculous protection that God granted Ka'ba at that time. In other words, they accept the Quranic account of this incident in its literality. Against these standard commentaries, against the apparent meaning of the Quranic verses, and in an interpretive mode of reading the miracle, Abduh (1922: 158) chooses to ascribe the defeat of the army to a chicken pox attack. He addresses the reader, saying, 'since the verses say that this disease resulted from the dry stones that birds were carrying, you may discern that these birds were actually mosquitoes like or even flies which carry the bacteria that cause this disease'. By rejecting to believe in one of the miracles revealed in the Quran, and which classical scholars of Quran accept in its literality, Abduh's attitude towards reason seems rather inconsistent. He accepts the divinity of the Quran, but refrains from accepting one of the miracles that the Quran told about in its classical, literalist interpretation.

Evidence to the growing impact of the gap between empirical evidence and Aristotelian logic comes also from his commentary on Al-Dawani's theological writings and his interpretation of prophethood. In what could be translated as Commentaries on the Explanation of Al-Dawani's Theology, which Abduh co-authored with al-Afghani, Abduh provides a definition of the 'prophet' that differs from the classical definition that he reiterates in The Theology of Unity. Rather than classically define the prophet's main feature as the one chosen to receive revelation from God, al-Afghani \& Abduh (2002) define the prophet as one created with the instinct of thinking and acting righteously. What is at stake in this definition is the concept of revelation. In fact, this is a novel definition of the prophet that cancels the possibility of revelation and interprets the prophet as a person with unique mental capabilities, a representation of prophethood that will also appear in the writings of al-Maraghi and Wajdi. These three examples of Abduh's modern thinking of religious truths or beliefs can be explained if we consider the difference that Islamic modernists started to articulate between empirical proof and logical arguments and their preference of the former method. Contestation of prophethood and miracles by presenting a new interpretation of them becomes one of the landmarks of Islamic modernists and reformers' thought in dealing with elements that they 
deemed irrational or inconsistent with scientific methods. The Islamic modernists' enthusiasm for empirical proof and its influence on this new understanding of prophethood and miracles can be traced back to the writings of Rafaah Al-Tahtawi.

Measured against the standards of its time, Rafaah Al-Tahtawi's writing mode of the Prophet's biography in 1865 exhibits a new outlook on the religious narrative of miracles. AlTahtawi sought to find a rational explanation for one of the most celebrated miracles associated with Prophet Muhammad, that of Muhammad's ascendance to heaven, known as al-Isra' wa alMi raj which is cited in the two main books of authenticated hadith, Sahih al-Bukhari and Sahih Muslim. Muslims believe that Muhammad's miraculous journey took him in one night from Mecca to Jerusalem and up to high skies where he led the rest of the prophets in prayers and then continued to the highest sky where he was closest to the divine throne itself. Al-Tahtawi tries to rationalize Muhammad's ascendance to the highest skies, using a slippery slope argument entrenched in scientific rhetoric. A close look at al-Tahtawi's narrative reveals the scientific language of fluid dynamics in his discussion of revelation and of the Prophet's ascendance to heaven. Al-Tahtawi (1977: 66) contends that if we deny the possibility of Muhammad's ascendance from earth to sky, then we have to suspect Gabriel's descending from heaven to earth to convey God's messages to the rest of the prophets before Muhammad. He writes that:

\begin{abstract}
... as it is rationally unlikely that a heavy body will ascend from the center of earth to the highest skies where the divine throne is, so it is unlikely that a light, spiritual body would descend from that space to the center of the world. Accordingly, if Prophet's ascendance was impossible in one night, then Gabriel's, the archangel's descent from the highest skies to Mecca in one night should also be judged impossible. However, if we accept this argument, then we have to suspect the prophecy of all prophets.
\end{abstract}

Al-Tahtawi's argument affirms belief in this miracle of Muhammad as long as belief in Gabriel's role as the messenger of heaven to the rest of the prophets persists. Al-Tahtawi's assessment of this miracle relies then on his inability or resistance to reject belief in the phenomenon of prophethood as such. The subtext of al-Tahtawi's argument is actually a call to contest prophethood. The implication of al-Tahtawi's analysis of this miracle is that the choice is not between Islam and secularism but between Abrahamic religions and atheism. In such a context, interpretation meant for Islamic modernists that irrational elements in religion, such as miracles, must have an explanation that appeals to empirical sensibilities and natural causes as the lesser of evils if these miracles could not be denied altogether.

In a leap over Abduh's new interpretation of one miracle, some Islamic modernists rejected the miraculous element, which cannot be accepted on empirical base. For example, Mustafa Al-Maraghi (1881-1945) who headed al-Azhar (Intermittently during 1928-29 and 1935-45) and who wrote the preface to Muhammad Hussein Haikal's famous Hayat Muhammad (the Life of Muhammad), writes that the only miracle of Prophet Muhammad is the Quran, which is an abstract miracle, not a concrete one. Al-Maraghi (1933) glorifies the Quran as an abstract miracle, precisely because it does not violate natural laws; the Quran may have been the intellectual product of a genius in terms of its linguistic grandeur, envisioning of morality, and power of social organization. By deciding that the Quran is the only miracle of the Prophet, al-Maraghi crystallizes the new trend amongst Islamic modernists, namely the suspicious attitude towards miracles.

At another level of conciliating Islam with the Western Enlightenment through the exclusion of the miraculous, Farid Wajdi (1991), in line with Al-Maraghi, sees that the other great miracle of Muhammad, next to the Quran, is the social revolution that he started in the Arabian Peninsula. The title of his famous book, Al-Sirah al-Muhammadiyyh tahta dawu al-'Ilm wa al-Falsafah (The Prophet's Biography under the Light of Science and Philosophy), prepares the reader for Wajdi's dismissal of mystical elements associated with the prophethood of 
Muhammad. Wajdi assesses the prophethood of Muhammad, looking at him through the lens of a social scientist to stress the social changes which Prophet Muhammad instigated as the biggest miracle of all. By doing so, Wajdi rejects the reported narratives concerning many miracles and abandons literal interpretation of miracles. Under a chapter titled Things that Defy Natural Laws and Which Took Place during Badr Battle, Wajdi explains his approach to the Prophet's biography in what relates to miracles, calling narratives which included them 'myths of religions'. He is of the opinion that 'such things did take place during Muhammad's age', but qualifies this opinion through this clarification:

\begin{abstract}
I do not mean to refer to incidents such as opening of his chest, the cloud shade, and the split of the moon, ... etc., for these cannot be proved by tangible evidence, or may have been misinterpreted. By Prophet's miracles I mean the social and literary upheavals which Prophet Mohammad instigated within less than a quarter of a century; these upheavals which nations had missed for many centuries and long periods (Farid Wajdi 1991: 184).
\end{abstract}

Wajdi's foregrounding of the social role that the Prophet played in his society downplays the mystical elements in the Prophet's life and in the foundation of religion in general. Wajdi's reference to these particular miraculous incidents takes on a special importance because at least two of them, the split of the moon and the opening of the chest, are cited in Sahih alBukhari and Sahih Muslim as part of authenticated Prophetic sayings over which there is no controversy among 'scholar or conservative scholars of religion; hence, it is a grave sin from the conservative scholars' point of view to dismiss these miracles as mythical. In addition, Wajdi's word choice of 'myths' to express miracle narratives derived from religious sources is very offensive to mainstream Muslims, especially if we take into consideration that his biography of Prophet Muhammad had been serialized in Nur al-Islam, a periodical that Al-Azahr started to publish in 1930. Wajdi's focus on the social changes that Prophet Muhammad instigated in his society satisfied Wajdi and others Islamic modernists' quest for the greatness of Muhammad as a man rather than as a prophet and contributed to bridging the cultural gap between a backward Islamic East and a progressive West.

\title{
The Views of Indian Islamic Modernists
}

Another mechanism through which Islamic Modernists thought they were reconciling Islam with reason, and consequently with the Western Enlightenment, was the rejection of classical scholarship of jurisprudence and philosophical theology. They refused to rely on the achievements of previous scholars of religion and downplayed the significance of juridical scholarship which accumulated around the Prophetic tradition and commentaries on the Quran, dismissing it as either a product of Aristotelian reason or as a cultural heritage which lacks the employment of modern, scientific methodology and discoveries. Shibli Nomani (1857-1914), an Indian scholar, finished writing his biography of the Prophet Sirat un-Nabi in Urdu language before his death in 1914. His view of the relationship of modern Muslims to the religious heritage introduces the controversy surrounding the authenticity of jurisprudence scholarship. In this work, he dedicates a whole section to talk about the methodology of what he called 'historical writing' by Muslim biographers of the Prophet and the scholars of his tradition. And in a separate chapter, he examines the principles implemented in reporting the prophetic tradition, and the textual and narrative strategies that reporters followed in order to authenticate sources of sayings and actions of the prophet. After explaining the extensive efforts that early scholars of prophetic tradition exerted in scrutinizing the narrators of the Prophet's sayings and actions, he explains the challenge that the binary of reason and reported knowledge or testimony, poses and has been posing for Islamic thinkers: 
Another great problem is whether a report that contradicts reason or an established fact, or surpasses all likelihood in view of circumstances definitely known, is to be accepted simply on the ground that the narrator's integrity is recognized and the chain of reporters unbroken. Ibn al-Jauzi has declared that reports that go against reason should be rejected without inquiring into the character of their narrators. But the controversy does not end here (Quoted in Moaddel \& Karman 2000).

Nomani's introduction to the textual criticism which accompanied the compilation of the Prophetic tradition reveals that the conflict between reason and reported knowledge is not new to practitioners of Islamic science of prophetic tradition. For this purpose, Nomani refers to Ibn al-Jawzi, a Hanbali scholar of Islamic sciences who was born in 1116, and who saw that rational interpretation of certain sayings of the Prophet should override the narrator's trustworthiness. Nomani's discussion remained analytical and documentarian, but conservative however, and did not evolve in the usual anti-clerical attitude as it did in discussions by other scholars, some of them were his compatriots, such as Sayyid Ahmad Khan, the pioneer of Islamic modernity in today's Pakistan, and the Egyptian Farid Wajdi. For both of these thinkers, Prophetic tradition, jurisprudence, and Islamic theology scholarship were facilitated by analogical arguments; hence, Muslims had to abandon this type of scholarship if they wanted to join Western modernity and progress, whose scientific basis is empiricism.

Khan (1817-1898) considers that a report or a Prophet's saying can be rejected if it goes against reason. His criteria for rationality meet with those of his contemporaries in Egypt, such as Wajdi. One of the reasons he thinks a Prophetic saying should be rejected is that it includes references to supernatural events or miracles. In his efforts to develop critical criticism of the Prophetic Tradition, Khan lists the categories of such Prophetic sayings, writing that: "when a truly critical scholar (muhaqiq as against muqallid -'muhaqiq' means 'critical scholar', one who is capable because of his advanced knowledge of criticizing scholars who came before him, while 'muqallid' is a follower of another scholar) examines them then he will judge that their being supernatural [i.e. reporting events or giving teachings of supernatural character] and their militating against reason are sufficient ground for holding them to be unreliable and unacceptable" (Quoted in Troll, 1978: 142). What is significant in this quote here is Khan's use of the word 'sufficient'. This word implies that Khan encourages those who do not have expertise in Prophetic Tradition, as a discipline of study and investigation, to reject Prophetic sayings if deemed irrational or cannot be proved empirically. This preference that Kahn gives to experimental reason over other criteria of authenticity is manifest also in the attack he launched against practitioners of Islamic jurisprudence and theology. If a critical attitude toward Prophetic tradition was the implication resulting from rejection of a particular hadith, Khan's writing shows a more lucid rejection of jurisprudence and theology scholarships precisely because of their employment of analogical reasoning. Khan writes commenting on the conflicting views of reason, to assert that religion should not and need not have a philosophical foundation. If classical scholars see that rational and analogical arguments constitute the basis of faith, Khan rejects such faith and looks forward to a religion whose elements can be verified through experimentation.

Khan in one of his lectures aims at excluding a specific understanding of reason and, through this exclusion, at rebelling against the classical scholarship of religious Islamic sciences. He embraces the Enlightenment's paradigm of progress which includes belief and trust in empirical science. In the course of his discussion, Khan (2007) attempts to build a correspondence between the reception of Greek wisdom by early Muslims and the reception of the principles of Western empirical science during his time. Neglecting to mention how Muslim theologians incorporated Greek philosophy into their scholarship, in what later became known as 'Ilm al-Kalam precisely to prove fundamentals of faith from a philosophical point of view, Khan states that tenets of Greek wisdom and philosophy 'were in disagreement with the tenets of customary Islam' but 'Muslim scholars of that time accepted them like religious tenets. The 
contrast that Khan draws between Greek philosophy and modern Western science becomes his way to expedite the reception of Western Enlightenment in Islamic societies. For him, when Muslims realize this distinction, it will be easier for them to change their conviction in the significance of Greek philosophy and to abandon analogical arguments and reasoning, processes of thought which are considered essential in jurisprudence scholarship and research. Khan (2007: 35) declares that:

\begin{abstract}
. . . because the tenets of former wisdom were based on rational and analogical arguments and not upon experience and observation. It was very easy for our forbears whilst sitting in the rooms of mosques and khanqahs, to disprove teaching arrived at by analogous reasoning ... Today doctrines are established by natural experiments [i.e. experiments in natural science] and they are demonstrated before our eyes. These are not problems of the kind that could be solved by analogical arguments or which can be contested by assertions and principles which the scholar of former times have established.
\end{abstract}

Thus, for Khan, the conflict between the epistemology of the Enlightenment and that of Greek philosophy mirrors the conflict between Islam as the jurisprudence scholar fashions it and between real Islam which Khan sets out to reveal. In addition to unjustifiably contrasting analogical reasoning to empirical knowledge, Khan's argument suffers from oversimplification of the role of Aristotelian reason in jurisprudence and theology, and from reducing Islam to jurisprudence.

Finally, in a defensive mood against his contemporary Western detractors of Islam, such as William Muir, he resolves the conflict between Islam and Western modernity by identifying Islam with nature, taking on the responsibility of defining Islam for what it is, not for what 'ulama [scholars of jurisprudence] and preachers have fashioned' and by attempting to redefine reason. He decides that Islam should be in 'correspondence with the natural disposition of man, or with nature', declaring: ". . I I formulated that 'Islam is nature and nature is Islam. God is the Creator of all things, as He is the Creator of Heaven and earth and what is in them, and of all creatures; so is He also the Creator of nature. What a tremendous slander is it, therefore, why my opponents state that I call nature Creator-or God Forbid-nature God" Khan (2007: 37). Khan's opponents had accused him of being a deist amongst other accusations. His contemporary scholar of religion and modernist, al-Afghani, saw in this identification between Islam and nature an endeavor to introduce materialism into Muslim societies (Hournai 1983). AlAfghani's view could be justified because Khan did not provide a convincing analysis of the identification process. Khan wanted to identify Islam with nature, but, as Troll (1978: 174) observes that his thought is opaque in that he does not clearly define 'nature' and 'reason', his two fundamental concepts. In his Tafsir, Khans seems to have defined reason as 'fitrat' which means in Urdu 'instinctive knowledge', 'a natural way of knowing, independent of the authority of revelation' (Troll 1978) or the authority of testimony.

In Egypt, Farid Wajdi's writings echoed those of Khan on more than one level. He carried out a similar process of identification between Islam and science and fiercely attacked previous scholarship for its engagement in philosophy and logic. Farid Wajdi (1912) applauds 'European science' in his magazine al-Hayah for its role in motivating people to rebel against old notions regarding their beliefs. European science, Wajdi (1912: 3) mentions: "was born four centuries ago and showed man through tangible evidence that religions' age had faded, and that their teachings do not benefit man a wee bit". He praises empirical science then tries to find parallels between new scientific methods and Islam. As Khan does; in order to reconcile his belief in Islam with his commitment to scientific methodology, he has to foreground those features in Islam that he thinks are compatible with the Western Enlightenment. Wajdi shows Muslims that Islam is not the source of their dilemma, their falling behind the West, but ignorance of what real Islam is. When he lists the fundamentals of real Islam, he mentions 'studying the universe' 
as a natural, standard method to believe in God. This is the empirical frame of thought that Muslims have to follow rather than turn to philosophy in order to prove fundamentals of religion, which is a deviation from Islam. This is also the basis that he provides for identifying Islam with modern, scientific thought.

Wajdi (1912: 115) dramatizes his opinion in a series of imagined conversations that take place between four characters, 'the civilized', who is a secularist; 'the reformist', who is trying to reconcile Islam with modernity, 'the imitator/follower', who represents the conservatives, and 'the moderate' whose task in the dialogue was only to coordinate the conversation. Performing the 'reformist' voice, Wajdi declares that Islam has become two religions, not one. The first religion is a religion which was revealed through prophets starting with Adam and ending with the Prophet Mohammad. It is a religion that had been kept in the Quran. The Muslim international community (umma) lived its life according to this religion until interpretations and speculations prevailed the intellectual life of Muslims and turned their religion into a stagnant form that opposes the vitality of the Quran. This stagnant form, which Wajdi (1912: 15) rejects, is a composite of 'divine and prophetic speeches mixed with opinions of scholars from different generations' whereas 'in the early stage of Islam, the Quran was the primary source and the Prophetic tradition was a commentary on it. Wajdi (1912: 137) is very convinced of this binary construction of Islam to the extent that he rewrites the Islam-modernity discussion, and even the Islam-West encounter, in terms of these two imagined religions; hence, all what Muslims need to do in order to modernize their countries and catch up with Europeans is to give up the stagnant form of Islam and to revert back to the original Islam. 'In fact', he adds 'the war between Europe's civilization and us is a war between the two kinds of Islam. And everybody knows that the huge difference between the two grants European civilization with victory'. To achieve what Europeans have achieved, Wajdi believes that Muslims should get rid of the stagnant form of Islam which came as a result of exaggerated imitation and he calls Muslims to be more critical of traditional scholarship.

With a sense of satire similar to that of Khan against classical scholars of religion, Wajdi (1912: 15) sees that divisions among followers of different religions are due to their reliance on their own minds and ideas in gaining knowledge, instead of relying on 'stable, natural origin' such as the methodical investigation of the universe and other creatures, in which case they would unite, like scientists of nature united in their conclusions. He lays the guilt of these divisions over the shoulder of religion scholars, accusing them of being in a state of acute division because religion is based on imagination and opinion'. In Al-Islam Din 'Am Khaled, he writes that: "Islam is not traditions, heritage, opinions and interpretations; rather it is the instinct (of religion), pure and simple" (Wajdi 1932). But for him, these opinions and interpretations are partially the result of previous scholars' engagement with logic; engagement in logic and philosophical debates has misled Muslims rather than enlightened them. As a result, he asks Muslims to abandon this heritage and to go back to the origin of Islam, which is belief in God based on studying nature, and resorting to Quran in solving contemporary issues without following previous scholars and their interpretations (Wajdi 1912). While early Muslims followed pure Islam, their successors developed 'their own opinions, and they relied on logic, which was translated from Greek, to defend fundamentals of Islam rather than relying on probing the universe' (p. 15). Criticizing the prevalence of analogical arguments in religious scholarship and its development into a standard practice of the scholars of Islam, Wajdi considers resorting to analogical arguments as opposed to empirical evidence a deviation from Islam that is responsible for the backward state of Muslims. In his ardent desire to reform Muslims, he neglects to historicize the emergence of Islamic theological, philosophical scholarship. He does not refer to the historical necessities that lead to the development of this scholarship after the death of Prophet Muhammad and the contact between Muslims and others from different cultures and traditions. The need to convince these new peoples of the credibility 
of Islamic faith, especially in its focus on the oneness of God, resulted in the development of a group of scholars who studied Greek philosophy and used it to defend the new religion.

As a conclusion, discussions on reason and its relationship to Islam were generated during the turn of the twentieth century as a result of the debates over the question of modernizing Arab and Muslim societies. These discussions swept vast geographic spaces of Muslim countries across Asia and Africa. Prominent figures of Islamic modernism thought that the shortest way to transforming Muslim societies was to commit to the epistemology of Western Enlightenment. Aiming at reconciling Islam with Western Enlightenment, their discourse on reason bifurcated into discussions on interpretations of miracles and prophethood, the role analogical arguments play in theological and juridical scholarships, and the reliability of reported sacred knowledge. Interlocutors negotiated epistemology of sacred knowledge according to challenges put forth by the paradigm of European Enlightenment. Many of these discussions had a predecessor in the Western encounter between religion and the Enlightenment. The distinction between empirical proof and analogical argument that Islamic modernists foregrounded, influenced by the Western Enlightenment, stands behind many of their reconciliatory strategies. Most Islamic modernists were living dilemmas between their allegiance to their religion and their commitment to what they thought was the outright, scientific methodology which generated the tremendous industrial and scientific progress that dazzled them. This dilemma existed because European proponents of secularism constructed an oppositional binary between the dogmatic and inexplicable beliefs in religion as opposed to the lucid, concrete, and testable principles of a modern secular society based on science and experimental reasoning. To resolve this dilemma, Islamic modernists translated a binary construction of reason into a binary construction of Islam. With an empiricist prejudice, Islam became the spiritual site where faith can be accepted as long as it can be rationalized through observation and evidence only, while analogical and philosophical arguments were seen as part of a tradition that goes against all what modernity stands for in the mind of Islamic modernists: innovation, progress, and freedom of thought Islamic modernists' enthusiasm for this binary construction of Islam had its ebbs and flows over the individual careers, resulting into different degrees of allegiance to what they envisioned as the critical reason of modernity.

\section{References}

Abduh, M. 1922. Tafseer Juzu' 'Amma. Misr: n.p. 2004. The Theology of unity. I. Mussad and K. Cragg (trans.). Kuala Lumpur: Islamic Book Trust.

al-Afghani, J.D \& Abduh, M. 2002. Al-Ta'liqat 'ala sharh al-'aqa'id al-'adudiah. In, S.H.K Shahi (ed.). Cairo: Maktabat al-Shourouq Addawliya.

al-Ansari, M. J. 1996. Al-Fikr al-'Arabi wa sra' al-addad. Beirut: Al-Mu'assat al-'Arabiah li alDirasat wa al-Nashr.

Antun, F. 1988. Ibn Rushd wa falsafatuhu ma' nusus al-munathara bayn Muhammad Abduh wa Farah Antun. In, Tizini, T. (ed.). Beirut: Lebanon: Dar al-Farabi.

Breuninger, S. 2009. Irish clergy and the Deist controversy: two episodes in the early British Enlightenment. Religion in the Age of Enlightenment 1: 197-224.

Euben, R. L. 1999. Enemy in the Mirror: Islamic Fundamentalism and the limits of Modern Rationalism. Princeton: Princeton University Press.

Ibrahim, H. 1978. Rithaa Muhammad Abduh. In, A. Amin, A. al-Zein \& I. al-Abiari (Eds.). Diwan Hafiz Ibrahim, pp. 458-63. $3^{\text {rd }}$ edition. Cairo: Al-Hai'a al-Massriyya li al-Kitab.

Haj, S. 2009. Reconfiguring Islamic Tradition: Reform, Rationalist and Modernity. Stanford: Stanford University Press.

Hamilton, P. 1996. The Enlightenment and the birth of social sciences. In, Hall, S. (ed.). Modernity: An Introduction to Modern Societie, pp. 19-54. Cambridge: Blackwell. 
Hourani, A. 1983. Arabic Thought in the Liberal Age. Cambridge: Cambridge University Press.

Khan, S.A. 2007. Islam: the religion of reason and nature. In, J. Donohue \& J. L. Esposito (Eds.). Islam in Transition: Muslim Perspectives, (pp. 35-37). Oxford: Oxford University Press.

Lock, J. 1990. An Essay Concerning Human Understanding. Raleigh, N.C: Alex Catalogue, accessed June 2, 2014. http://search.ebscohost.com/login.aspx?direct=true\&scope=site\&db= nlebk\&db=nlabk\&AN=1085946.

Locke, J. \& Higgins-Biddle, J. C. 1999. The Reasonableness of Christianity: As delivered in the Scriptures. Oxford: Clarendon Press.

al-Maraghi, M. 1933. The Life of Muhammad. 14th edition. Cairo: Dar al-Ma`arif.

Moaddel, M. \& Talattof, K. 2000. Contemporary Debates in Islam: An Anthology of Modernist and Fundamentalist Thought. New York: St. Martin's Press.

Muhammad, M.F. 1932. Al-Islam Din 'am Khaled: Tahlil daqiq l'osuli al-Din al-Islami fi dauw al'Ilm wa al- Falsafa. Cairo: Matba`at Da'irat Ma`arif al-Qarn al-'Isyrin.

Sabri, M. 1981. Mawqef al-'aql wa al-'ilm wa al-din min Rabb al-'alamin. Beirut: Dar Ihya' alTurath al-`Arabi.

al-Tahtawi, R.R. 1976. Nihayat al-i jaz fi sirat sakin al-Hijaz. In, F. Abu Zaid (ed.). Cairo: Dar alFikr wa al-Fan.

Tamimi, A. 2000. The origins of Arab secularism. In, A. Tamimi \& J.L. Esposito (Eds.). Islam and Secularism in the Middle East, pp. 13-28. New York: New York University Press.

Troll, C.T. 1978. Sayyid Ahmad Kahn: A Reinterpretation of Muslim Theology. New Delhi: Vikas Publishing House Pvt. Ltd.

Wajdi, M.F. 1912. Al-Hayah: Collected articles by Farid Wajdi. Cairo: n.p. 1991. Al-Sirah al-Muhammadiyyah tahta dawu al-`im wa al-falsafah. In, M.R. Al-Bayyumi (ed.). Cairo: Al-Dar al-Misriyyah al-Lubnaniyyah. 